\title{
Consent and Brain Trauma in Schools
}

Adam White

[Lecturer in Sport and Physical Education, University of Bedfordshire, Bedford, UK]

Adam.White1@beds.ac.uk

Dr. Stefan Robinson

[Doctoral Researcher, Dept of Sport and Exercise, University of Winchester, Winchester, UK]

\section{Introduction}

In a recently published edition of the Journal of Physical Education, Recreation and Dance, we read with interest responses given by readers on 'how should coaches, parents and participants be informed of the risks and rewards of their participation' (2017: 54) in sports with a risk of head trauma. Over the past decade, increasing attention has been forthcoming on the issues of traumatic brain injuries, repetitive sub-concussive traumas and the long-term, and sometimes fatal, implications of concussion (McKee et al. 2014) often focusing on contact sports, such as American Football, Ice Hockey or the various codes of Rugby.

\section{Traumatic Brain Injuries}

Since 2005, and the discovery of Chronic Traumatic Encephalopathy (CTE) in an American Football player (Omalu et al. 2005), concerns about the long-term degenerative effects of repetitive head trauma have been a noticeable worry for those involved with sport (McCrory et al. 2017). With concussive injuries being linked to Alzheimer's disease and dementia (Li et al. 2017), as well as a range of socio-negative life outcomes (Sarlasen et al. 2016), the widespread anxiety among the stakeholders of sport is not surprising. Recent studies show that CTE has been identified in 110 of 111 ex-NFL brains examined posthumously (Mez et al. 2017). Additionally, concerns are common regarding second impact syndrome, which is caused by a second traumatic brain injury before the resolution of the first. In the UK, fourteenyear-old Benjamin Robinson died because of second impact syndrome whilst playing rugby in a school game (Pollock 2014).

At present, there are limited strategies for reducing the risks associated with concussions in high impact contact sports, such as American Football or Rugby (Anderson and White 2017). For example, protective headgear is ineffective (Benson et al. 2009), the effectiveness of education initiatives is lacking evidence (Fraas and Burchiel 2016; White, Gamble and Batten 2016) and the correct tackle technique is yet to prove successful in concussion reduction (McCrory et al. 2017; Pollock, White and Kirkwood 2017). Considering the hierarchy of risk controls, substituting the risk is the next appropriate option; accordingly, replacing the contacts or tackles with touch or tag is a more appropriate way forward (Batten et al. 2016). In fact, when researchers removed the body check in Ice Hockey, the risk of brain injuries reduced three-fold (Black et al. 2016).

\section{Consent in Physical Education}

In the general sporting and physical education context, consent is implied through participation and therefore the associated risks of the sport are accepted (James 2017). When participation in an activity is voluntary, the socially acceptable level of risk associated with that activity is higher in comparison to everyday activities (Fuller 2007; Trimpop and Zimolong 2006). However, physical education is often a statutory element of the school curriculum - like in the United Kingdom (AfPE 2016) - and therefore students are required to participate, irrespective of the view of the student or their parent(s)/guardian(s). In research on school-boys in Australia, Pringle and Markula (2005) found that 
because of school structures, cultures, and peer pressures, children felt pressured to participate in contact sports through fear of being de-masculinized if they did not.

In a study of predominantly private schools in the United Kingdom, Nyiri (2016) found that 77 percent of the sample of 116 schools made full rugby a compulsory school sport. More worryingly, in the state sector of education 83 percent of schools that deliver rugby make it a compulsory activity for boys (White and Anderson 2017). If a parent were to express a desire for their child to withdraw from the activity, 11 percent of schools would use disciplinary action. This increases to 21 percent of schools if a student were to attempt to withdraw (White and Anderson 2017). Sport, therefore, is not a voluntary activity in this setting and this becomes particularly problematic when contact sports have a higher risk of injury comparative to other sporting and everyday activities (Chieng, Lai and Woodward 2017).

\section{Informed consent}

Of course, there are occasions where young people and their parent(s)/guardian(s) will want the choice to participate in contact sport, and as such expressed and informed consent is necessary. For consent to be informed, clear and understandable information on the risks and benefits associated with an activity should be freely available to those making decisions (Weinberg 2016). Unfortunately, epidemiological data is often presented as the number of injuries in relation to 1000 hours of exposure (Fuller et al. 2007) and is contained in academic journals, often behind a pay-wall. The lay person, such as most coaches, parents and athletes, are often unable to access the publications. Instead, presenting injuries as a probability (Parekh et al., 2011) or in relation to other everyday activities (Fuller 2007) is somewhat more useful.

Unfortunately, there has been occasions whereby sporting bodies have neglected to disclose the risks of contact sport with athletes or other stakeholders. For example, World Rugby has recently been criticized for presenting misleading injury data as part of an infographic (Piggin and Pollock, 2017). Such actions inhibit a participants and their parent(s)/guardian(s) ability to make informed choices.

\section{Our view}

Contact sports have a high and serious risk of injury, with a propensity for concussive and subconcussive head trauma. Likewise, the increasing evidence on the long-term implications of mild traumatic brain injuries suggests that contact sports, is not an activity that young people should be compelled to participating in.

Unfortunately, many schools elect to include contact sport (American Football, Ice Hockey, Rugby) in their physical education curriculum, with parents and children often not given any right to give or withdraw consent.

We believe that as contact sports have a high risk of injury and those injuries have potential long-term implications, both young people and their parent(s)/guardian(s) should be required to give informed consent before participation. Without such consent, contact sport has an unacceptable level of risk. It is more appropriate, therefore, in accordance with the precautionary principle, to replace the tackle with a touch (and remove other forms of contact) until there is evidence that it is safe to reintroduce contact to the school environment.

\section{References}

Anderson, E. \& White, A. (2017). Sport Theory and Social Problems: A Critical Introduction (2 ${ }^{\text {nd }}$ Edition). Routledge. 
Archbold, H. A. P., Rankin, A. T., Webb, M., Nicholas, R., Eames, N. W. A., Wilson, R. K., ... \& Bleakley, C. M. (2015). RISUS study: Rugby injury surveillance in Ulster Schools. British journal of sports medicine, bjsports-2015.

AfPE (2016). Safe Practice in Physical Education, School Sport \& Physical Activity 2016. Coachwise.

Batten, J., White, A. J., Anderson, E., \& Bullingham, R. (2016). From management to prevention: the new cure for sports concussion. British journal of sports medicine.

Bullingham, R., White, A., \& Batten, J. (2017). Response to:'Don't Let Kids Play Football': a Killer Idea. British Journal of Sports Medicine.

Carter, M. (2015). The unknown risks of youth rugby. BMJ, 350, h26-h26.

Chieng, M., Lai, H., \& Woodward, A. (2017). How dangerous is cycling in New Zealand?. Journal of Transport \& Health.

Fraas, M. R., \& Burchiel, J. (2016). A systematic review of education programmes to prevent concussion in rugby union. European journal of sport science, 16(8), 1212-1218.

Freitag, A., Kirkwood, G., Scharer, S., Ofori-Asenso, R., \& Pollock, A. M. (2015). Systematic review of rugby injuries in children and adolescents under 21 years. British journal of sports medicine, 49(8), 511519.

Fuller, C. W. (2007). Managing the risk of injury in sport. Clinical Journal of Sport Medicine, 17(3), 182187.

Fuller, C. W., Molloy, M. G., Bagate, C., Bahr, R., Brooks, J. H., Donson, H., ... \& Quarrie, K. L. (2007). Consensus statement on injury definitions and data collection procedures for studies of injuries in rugby union. British journal of sports medicine, 41(5), 328-331.

Haseler, C. M., Carmont, M. R., \& England, M. (2010). The epidemiology of injuries in English youth community rugby union. British journal of sports medicine, 44(15), 1093-1099.

King, D., Hume, P. A., Brughelli, M., \& Gissane, C. (2015). Instrumented mouthguard acceleration analyses for head impacts in amateur rugby union players over a season of matches. The American journal of sports medicine, 43(3), 614-624.

Kirkwood, G., Parekh, N., Ofori-Asenso, R., \& Pollock, A. M. (2015). Concussion in youth rugby union and rugby league: a systematic review. British Journal of Sports Medicine, 49(8), 506.

Li, Y., Li, Y., Li, X., Zhang, S., Zhao, J., Zhu, X., \& Tian, G. (2017). Head Injury as a Risk Factor for Dementia and Alzheimer's Disease: A Systematic Review and Meta-Analysis of 32 Observational Studies. PloS one, 12(1), e0169650.

McCrory, P., Meeuwisse, W. H., Aubry, M., Cantu, B., Dvořák, J., Echemendia, R. J., ... \& Sills, A. (2013). Consensus statement on concussion in sport: the 4th International Conference on Concussion in Sport held in Zurich, November 2012. British journal of sports medicine, 47(5), 250-258. 
McCrory, P., Meeuwisse, W., Dvorak, J., Aubry, M., Bailes, J., Broglio, S., ... \& Davis, G. A. (2017). Consensus statement on concussion in sport-the 5th international conference on concussion in sport held in Berlin, October 2016. Br J Sports Med, bjsports-2017.

McKee, A. C., Daneshvar, D. H., Alvarez, V. E., \& Stein, T. D. (2014). The neuropathology of sport. Acta neuropathologica, 127(1), 29-51.

Morrissey, D. I., Good, D., \& Leonard, M. (2016). Acetabular fractures in skeletally immature rugby players. BMJ case reports, 2016, bcr2015211637.

Omalu, B. I., DeKosky, S. T., Minster, R. L., Kamboh, M. I., Hamilton, R. L., \& Wecht, C. H. (2005). Chronic traumatic encephalopathy in a National Football League player. Neurosurgery, 57(1), 128-134.

Palmer-Green, D. S., Stokes, K. A., Fuller, C. W., England, M., Kemp, S. P., \& Trewartha, G. (2013). Match Injuries in English Youth Academy and Schools Rugby Union An Epidemiological Study. The American journal of sports medicine, 41(4), 749-755.

Piggin, J., \& Pollock, A. (2016). World Rugby's erroneous and misleading representation of Australian sports' injury statistics. British journal of sports medicine, bjsports-2016.

Pfister, Ted, et al. "The incidence of concussion in youth sports: a systematic review and metaanalysis." British journal of sports medicine 50.5 (2016): 292-297.

Pollock, A. (2014). Tackling Rugby: What Every Parent Should Know. Verso Books.

Pollock, A., White, A.J., \& Kirkwood, G. (2017). Evidence in support of the call to ban the tackle and harmful contact in school rugby. A response to World Rugby. British Journal of Sports Medicine. Pringle, R., \& Markula, P. (2005). No Pain Is Sane after All: A Foucauldian Analysis of Masculinities and Men's Rugby Experiences of Fear, Pain, and Pleasure. Sociology of sport journal, 22(4), 472-497.

Roberts, S. P., Trewartha, G., England, M., Goodison, W., \& Stokes, K. A. (2016). Concussions and head injuries in english community rugby union match play. The American Journal of Sports Medicine, 0363546516668296.

Sariaslan, A., Sharp, D. J., D’Onofrio, B. M., Larsson, H., \& Fazel, S. (2016). Long-term outcomes associated with traumatic brain injury in childhood and adolescence: A nationwide Swedish cohort study of a wide range of medical and social outcomes. PLoS Med, 13(8), e1002103.

Sport Collision Injury Collective (2016). Open letter: preventing injuries in children playing school rugby. 1 March 2016. http://www.sportcic.com/resources/Open\%20Letter\%20SportCIC\%20March1st\%202016.pdf (accessed 1 May 2016).

Stewart, W., McNamara, P. H., Lawlor, B., Hutchinson, S., \& Farrell, M. (2015). Chronic traumatic encephalopathy: a potential late and under recognized consequence of rugby union?. QJM, hcv070. 
Trimpop R, Zimolong B. Risk acceptance. In: JM Stellman (Editor) Encyclopaedia of Occupational Health and Safety, Fourth edition. Available at: http://www.ilo.org/encyclopedia/?hdoc\&nd=857000002. Accessed: 24 November 2006.

Weinberg, J. D. (2016). Consensual Violence: Sex, Sports, and the Politics of Injury. Univ of California Press.

White, A. J. \& Anderson, E. (2017) Banning the schools' rugby tackle: academic initiative and inept governmental response to protect children from compelled child abuse. Sport and Politics Study Group Annual Conference, Thursday 16 and Friday 17 March 2017.

White, A.J., Gamble, T., \& Batten, J. (2016). Safety in youth rugby: education is not the answer to the concussion crisis. British Journal of Sports Medicine Blog. 19 ${ }^{\text {th }}$ September 2016. Available here:

http://blogs.bmj.com/bjsm/2016/09/19/safety-youth-rugby-education-not-answer-concussion-crisis/

World Rugby. Response to 'Ban on Rugby tackling' petition in the UK. 2 March 2016. http://www. worldrugby.org/news/142105 (accessed 1 May 2016). 